Luxembourg Income Study Working Paper No. 259

Holes in the Safety Net? Social Security

AND THE ALLEVIATION OF POVERTY IN

a Comparative Perspective

Christina Behrendt

December 2000 


\section{Holes in the safety net? Social security and the alleviation of poverty in a comparative perspective}

Slightly revised version of a paper prepared for the ISSA Y ear 2000 Research C onference

in H elsinki, September 25-27, 2000

Christina Behrendt

D ecember 2000

University of Konstanz

D epartment of Politics and Management

Fach D 91

78457 Konstanz

G ermany

Tel. +49-7531-88-3705

Fax +49-7531-88-2381

christina.behrendt@uni-konstanz.de 


\begin{abstract}
Although highly-developed welfare states in the industrialised world spend a large share of their income on social security, poverty and social exclusion have not been eradicated. The persistence of income poverty in industrialised welfare states casts serious doubt on the effectiveness of social security schemes in alleviating poverty. This paper explores the poverty-alleviating power of social security in a comparative perspective on the basis of household micro-data from the Luxembourg Income Study. D o higher levels of social spending necessarily lead to a lower level of poverty, or does the effectiveness of poverty alleviation rather depend on how the money is spent? Special emphasis is placed on minimum income schemes. Which institutional structures have proved to guarantee an effective alleviation of poverty, and which ones are rather ineffective in this respect? What can be learned for future reforms?
\end{abstract}

\title{
Acknowledgements
}

This piece of research has greatly benefited from comments of Jens Alber, Frauke Kreuter, Wolfgang Lauterbach, Matthias Sacher, Martin Schölkopf, and a number of participants at the conference in Helsinki. 


\section{Table of Contents}

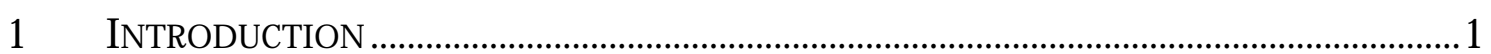

2 WHAT DO WE KNOW ABOUT POVERTY AND POVERTY ALLEVIATION IN IND USTRIALISED WELFARE STATES? ..............................................................................

2.1 Poverty in industrialised welfare states..................................................................

2.2 The redistributional impact of the welfare state .................................................... 4

2.3 Welfare state effort and the alleviation of poverty................................................

2.3.1 W elfare state effort and the incidenœ of poverty.................................................... 8

2.3.2 W elfare state effort and the redistributional impact of the welfare state....................10

3 ASSESSING THE EFFECTIVENESS OF SOCIAL POLICIES: UNSOLVED PUZZLES AND A POSSIBLE SOLUTION ………………………………..........................11

3.1 Limitations of the existing studies ....................................................................11

3.2 Focussing on the basic safety net of the welfare state..........................................13

4 THE BASIC SAFETY NET OF THE WELFARE STATE AND ITS EFFECTS ON THE ALLEVIATION OF POVERTY: EVIDENCE FROM BRITAIN, GERMANY AND SWEDEN .......................................................................................................

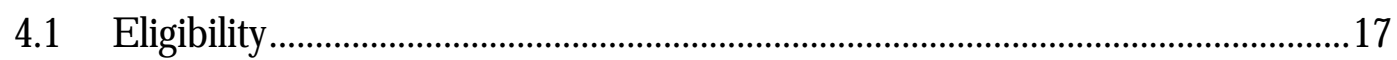

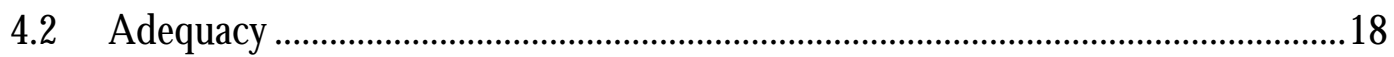

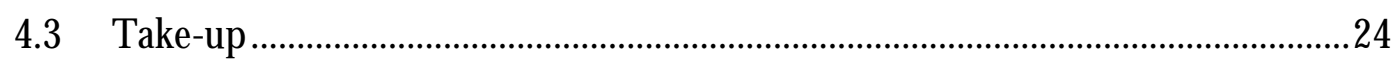

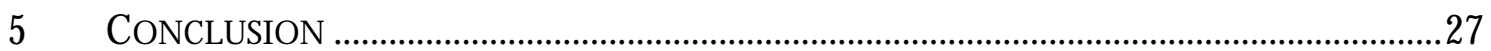

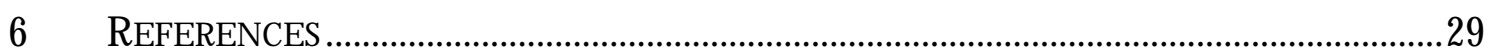

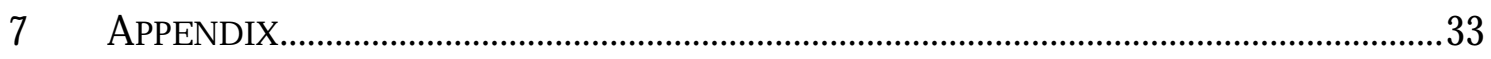

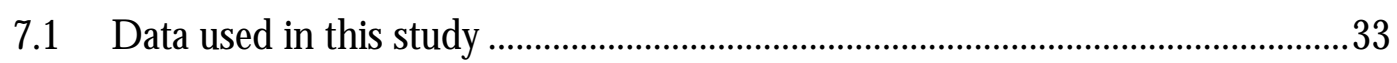

7.2 Methodology of the estimation of social assistance benefit levels........................33 


\section{Introduction}

Industrialised welfare states have established elaborate systems of income redistribution and spend a considerable proportion of their national income on social policies. In a complex wickerwork of taxes and transfers, resources are redistributed in multiple ways, between the rich and the poor, between the young and the old, between families with children and the childless, between healthy and sick people, and so forth. The redistributional impact of the welfare state is so large that some groups of the population even receive the largest part of their income from the welfare state.

Nonetheless, poverty has not been eradicated. The expansion of the welfare state during the $20^{\text {th }}$ century and the economic boom after World War II led many people to believe that poverty would disappear or would at last be reduced to an insignificant minimum affecting only marginal groups of the population. Yet, a sizeable proportion of the population live in economic poverty in all industrial welfare states. According to the most common standards used in international poverty analyses, on average roughly one in ten households live in relative poverty in OECD countries (cf. Atkinson et al. 1995).1

The persistence of poverty in industrial welfare states calls for an explanation. If these welfare states offer elaborate systems of income maintenance, why is there still a considerable amount of poverty? The alleviation of poverty has been one of the major aim of modern welfare states, if not the most important aim. Although welfare states differ in terms of aspiration, institutional design and policies, this objective is in principle embraced in all welfare states (cf. Goodin et al. 1999: 21-36). In this vein, Stein Ringen has proposed to use the issue of poverty alleviation as a yardstick for the general effectiveness of the welfare state.

„It is important to raise the issue of poverty, because of the historical significance of the problem, because its elimination has been the first priority of the welfare state, and because it offers an opportunity for discussing social policy on a basis of consensus. While there is a disagreement about the responsibility of government with regard to overall inequality, its responsibility in relation to poverty has been accepted for generations and is not seriously contested today. If poverty prevails, the welfare state is a failure." (Ringen 1987: 141; emphasis CB)

1 These poverty rates are based on a relative poverty line of $50 \%$ of national equivalised disposable household income. See Section 2.1 for a more detailed presentation of empirical evidence. 
If modern welfare states are not effective in alleviating poverty, their very purpose is fundamentally challenged, irrespectively of whether they are effective in achieving other goals or not. The persistence of poverty in highly-developed welfare states casts doubt on the fundamental operating procedures of income distribution and redistribution. What are the reasons for this apparent failure of the welfare state in alleviating poverty? Why are some countries more effective than others in this respect? What can explain these variations in effectiveness?

This paper explores the poverty-alleviating power of social security schemes in a comparative perspective on the basis of household micro-data from the Luxembourg Income Study. ${ }^{2}$ After a short descriptive overview over poverty rates in highly-developed welfare states, the available evidence on the effectiveness of the welfare state in terms of poverty alleviation and the relationship between social spending and poverty rates is briefly summarised. The paper argues that an effective alleviation of poverty is not only dependent of the level of social expenditure, but also to the question of how the money is spent. Especially minimum income schemes play a critical role in the alleviation of poverty and may be responsible for apparent "holes" in the social safety net. D rawing on the results of a larger research project, the following analysis of minimum income schemes in three countries Britain, Germany and Sweden - sheds some more light on the mechanisms of an effective alleviation of poverty.

\section{What do we know about poverty and poverty alleviation in in- dustrialised welfare states?}

\subsection{Poverty in industrialised welfare states}

Poverty still consitutes a wide-spread phenomenon in highly developed welfare states. The empirical picture of relative income poverty in industrial welfare states suggests that a sizeable proportion of the population find themselves below the poverty line, yet poverty rates and the structure of poverty vary. ${ }^{3}$ Chart 1 reports poverty profiles for a number of industrialised countries for the early 1990s. ${ }^{4}$ As in most comparative analyses, households are

2 D etailed information on the construction of this database can be found in Atkinson et al. (1995) and Smeeding et al. (1990).

3 For recent comparative analyses cf. Jäntti and D anziger (2000); Atkinson et al. (1995); Mitchell (1991); and Smeeding and Ross (1999).

4 The choice of countries is informed by the availability of recent data in LIS. 
considered to live in poverty if their disposable equivalent income is lower than $50 \%$ of the national median income. ${ }^{5}$ In order to account for different intensities of poverty, three additional poverty lines are applied. Households are deemed to live in „extreme poverty” if their income remains below a poverty line of $30 \%$ of median equivalent income; a poverty line of $40 \%$ demarcates "severe poverty”, whereas households with an income between $40 \%$ and $50 \%$ of median equivalent income are considered as living in "moderate poverty”. Households whose income exceeds the poverty line of $50 \%$, but remains below $60 \%$ of median equivalent income are considered as living „near poverty”. In Chart 1, countries are ranked according to their poverty rate at the $50 \%$ level, while the shading of the bars show different intensities of poverty or low income. ${ }^{6}$

Chart 1: $\quad$ Relative poverty in industrialised countries

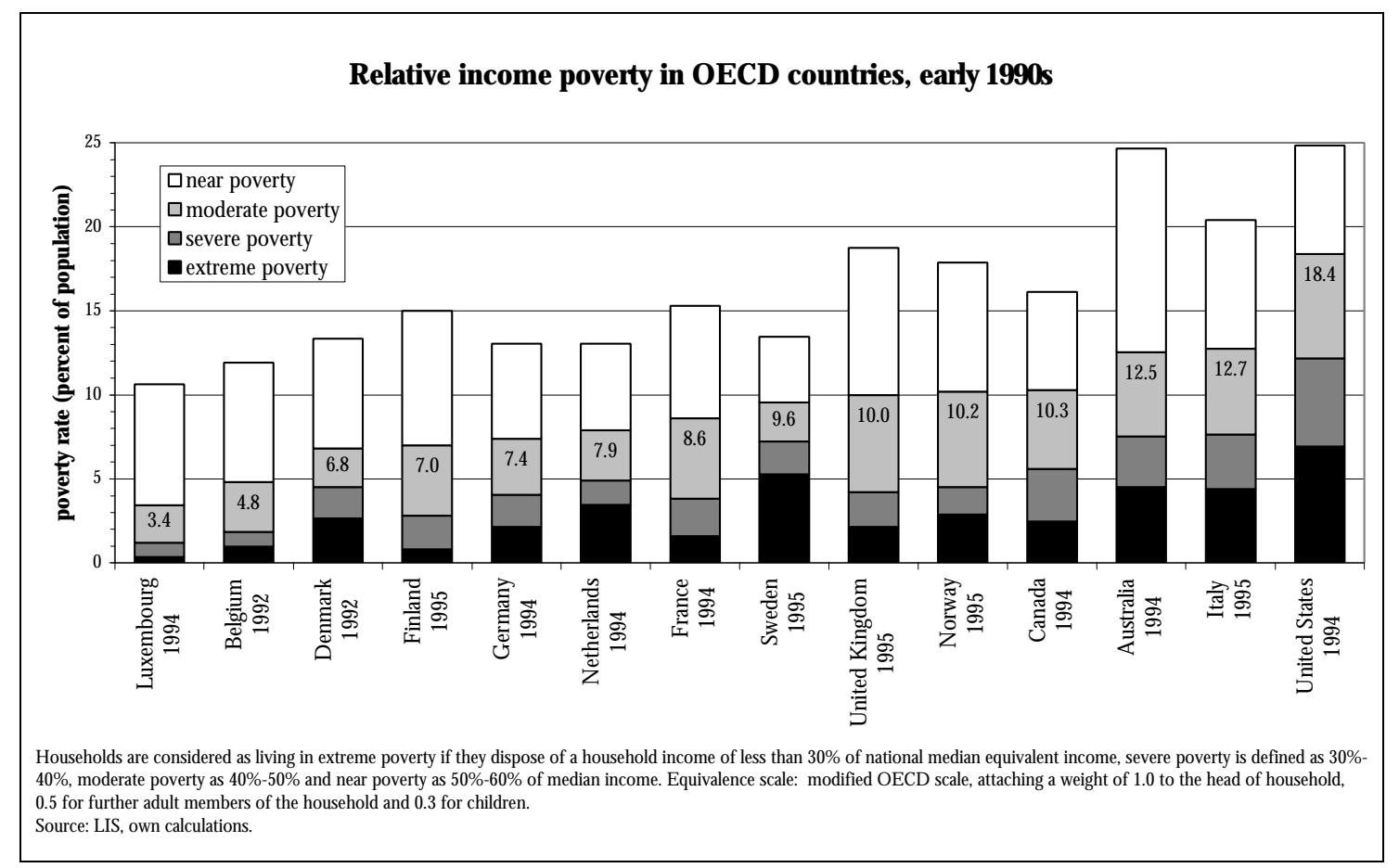

5

In order to account for variations in needs according to household size, equivalence scales are used to adjust household income according to the size and composition of the household (cf. Atkinson et al. 1995: 18-21; Buhmann et al. 1988). The "modified OECD equivalence scale" that is applied here attaches a weight of 1.0 to the head of household, .5 for each additional member of the household, and .3 for each child under the age of 18.

6 The LIS data referring to the United Kingdom is subject to Crown Copyright; has been made available by the Office for National Statistics through the ESRC D ata Archive; and has been used by permission. Neither the Office for National Statistics nor the ESRC D ata Archive bear any responsibility for the analysis or the interpretation of the data reported here. This disclaimer also applies to all following charts and tables based on LIS data. 
Chart 1 shows that a considerable share of the population live in relative income poverty in all industrialised welfare states, yet with a large variation across countries. With the exception of the extreme cases of Luxembourg and the United States, all industrialised countries in this sample display poverty rates in the band of $6 \%$ to $13 \%$ of the household population if poverty is defined as $50 \%$ of median equivalent household income. The lowest poverty rate of 3.4\% is found in Luxembourg, followed by D enmark, Finland, G ermany, the Netherlands, and France. The middle ranks are taken by Sweden, the United Kingdom, Norway and Canada, where roughly one tenth of the population live in poverty. Australia and Italy have poverty rates of some $12-13 \%$, but the at the very bottom of this ranking, we find the United States with a poverty rate of almost a fifth of the household population.

The profiles of poverty markedly vary across countries. Countries with similar poverty rates at the $50 \%$-level do not necessarily have the same amount of extreme and severe poverty and vice versa. For example, Denmark and Canada exhibit similar levels of extreme poverty, but markedly differ in terms of overall poverty at the 50\% level. Likewise, Denmark and Finland have similar levels of overall poverty, but divergent poverty profiles, especially in terms of extreme and moderate poverty. Besides, there is large variation in the share of the population living near poverty just above the $50 \%$ poverty line. If the poverty line was set at $60 \%$ rather than $50 \%$ of median income, Australia and the United States would both have poverty rates of around one quarter of the population, although poverty rates at the $50 \%$ level differ by as much as 6 percentage points. These different profiles of poverty are informed by differences in the income distribution in each country, but may also be caused by differences in the underlying databases.

\section{$2.2 \quad$ The redistributional impact of the welfare state}

The first glance on poverty rates in industrialised countries in Section 2.1 above has shown that a substantial proportion of the population live in income poverty even though elaborate systems of income redistribution. At face value, the presence of poverty in these countries suggests that the welfare state thus is not effective in alleviating poverty, but this issue deserves some more attention.

International variations in poverty profiles are not only driven by variations in the effectiveness of welfare state redistribution, but also by variations in socio-demographic and socio-economic structures, as theses factors put different strains on income transfer sche- 
mes (Kangas/ Ritakallio 1998b). ${ }^{7}$ An alternative approach allows to control some external effects on poverty, thus allowing a more refined analysis of the redistributional impact of the welfare state. The rationale of this approach is a comparison of pre- and postredistribution poverty rates, that is market income and disposable income, and the calculation of so-called Beckerman ratios (cf. Beckerman 1979). ${ }^{8}$

When comparative micro-data on income became more easily available in the 1980s, a number of studies has scrutinised the redistributive effect of the welfare state on the basis of Beckerman ratios. Mitchell's (1991) study is the most comprehensive account of the redistributive effectiveness of the welfare state based on the second wave of the Luxembourg Income Study (mid-1980s). She has identified distinct patterns of poverty reduction. Sweden, Norway, the Netherlands, France and Germany form a cluster of countries with a high effectiveness of taxes and transfers. A second, but less clear-cut cluster of lowperformance countries comprises Australia, Switzerland, Canada and the United States at the very bottom. ${ }^{9}$ The United Kingdom displays a distinct pattern of effectiveness of redistribution. Applying a low poverty line of $40 \%$ of the median income, effectiveness is even higher than for the high-performance countries; at the 50\%-level, for a 50\%-poverty line, and even more for a $60 \%$-line, Britain is located between the two clusters, or even comes close to the low-performance cluster (Mitchell 1991: 47, 51). A number of similar studies have largely confirmed Mitchell's results for different subgroups of the population, such as

7 Indeed, a comparison of Scandinavia and France has demonstrated that the French poverty rate would almost reduced to zero if social structure and labour market participation rates would correspond to the Scandinavian situation. By the same token, the Scandinavian countries would do much worse in poverty alleviation if they had the French social-economic situation (Kangas/Ritakallio 1998b).

8 The appeal of this method stems from its easy calculation and wide range of application. It allows the comparison of effectiveness across countries and over time without necessarily having to account for different institutional settings, as this broad approach side-steps a major problem in comparative research: Countries have organised their social transfers differently, and therefore the same goals are approached by various means (transfers or taxes, different forms of social insurance, etc.). It should be made clear, however, that only actual redistributional measures can be assessed. Further consequences of redistributional policies, such as changes in individual or collective behaviour or macro-economic performance cannot be captured by the methods employed.

9 The position of Australia stands in some tension to Castles' and Mitchell's (1993) re-definition of welfare state regimes that has classified Australia together with the United Kingdom as belonging to the "radical" world of welfare. In terms of poverty reduction, Australia takes a medium position between the United Kingdom and the "liberal" countries of Switzerland, Canada (with some characteristics of the "radical" type) and the United States (Mitchell 1991: 51), whereas Australia joins the United Kingdom in the reduction of inequality (Gini index) (Castles/ Mitchell 1993: 110). 
families (McFate et al. 1995; Förster 1994), single parent families (Hauser 1987; Hauser/ Fischer 1990), and the elderly (Shaver 1998).

Table 1 shows more recent empirical results on the redistributional impact of the welfare state, based on the most recent LIS data available for selected industrial countries. Whereas the first two columns show poverty rates before and after transfers and taxes (that is, for market income and for disposable income), the last two colums present the reduction of poverty in two ways, the absolute reduction of poverty rates in percentage points, and the relative reduction in percent. Countries are ranked according to their poverty rate after taxes and transfers. As the overall redistributional impact of the welfare state is strongly dependent on the public-private mix in the pension system, this table and the following charts are confined to the prime-age population, defined as households whose head is no older than 55 years. ${ }^{10}$

Table 1: $\quad$ The effectiveness of welfare state redistribution for primeage households, early 1990s (household head under 55)

\begin{tabular}{|c|c|c|c|c|c|c|c|}
\hline \multirow{2}{*}{$\begin{array}{l}\text { Country } \\
\text { (sorted by poverty rate after } \\
\text { redistribution) }\end{array}$} & \multicolumn{3}{|c|}{ Poverty Rate (rank order) } & \multicolumn{4}{|c|}{ Poverty Rate Reduction (rank order) } \\
\hline & $\begin{array}{l}\text { before taxes } \\
\text { and transfers }\end{array}$ & \multicolumn{2}{|c|}{$\begin{array}{l}\text { After taxes } \\
\text { and transfers }\end{array}$} & \multicolumn{2}{|c|}{$\begin{array}{c}\text { absolute } \\
\text { (percentage points) }\end{array}$} & \multicolumn{2}{|c|}{$\begin{array}{c}\text { relative } \\
\text { (percent) }\end{array}$} \\
\hline Belgium 1992 & $13.0 \quad(1)$ & 2.9 & (1) & -10.1 & $(8)$ & $-78 \%$ & (1) \\
\hline Finland 1995 & $25.7 \quad(10)$ & 7.9 & (2) & -17.8 & (2) & $-69 \%$ & (2) \\
\hline G ermany 1994 & 14.7 & 7.9 & (2) & -6.8 & (11) & $-46 \%$ & $(10)$ \\
\hline D enmark 1992 & 22.6 & 8.1 & (4) & -14.5 & (4) & $-64 \%$ & (3) \\
\hline France 1994 & 22.3 & 8.5 & (5) & -13.8 & (5) & $-62 \%$ & (5) \\
\hline Netherlands 1994 & 19.5 & 9.1 & (6) & -10.5 & (7) & $-54 \%$ & (7) \\
\hline Norway 1995 & 20.7 & 9.5 & (7) & -11.2 & (6) & $-54 \%$ & (7) \\
\hline United Kingdom 1995 & $26.2 \quad(11)$ & 9.8 & (8) & -16.4 & (3) & $-63 \%$ & (4) \\
\hline Australia 1994 & 20.2 & 10.4 & (9) & -9.8 & (9) & $-49 \%$ & (9) \\
\hline Canada 1994 & 21.0 & 11.7 & (10) & -9.3 & (10) & $-44 \%$ & (11) \\
\hline Sweden 1995 & $31.4 \quad(12)$ & 13.1 & (11) & -18.3 & (1) & $-58 \%$ & (6) \\
\hline United States 1994 & $21.6 \quad(7)$ & 18.2 & (12) & -3.4 & (12) & $-16 \%$ & (12) \\
\hline
\end{tabular}

$\mathrm{N}$ ote: Poverty rates are based on a poverty line of $50 \%$ of national median income, adjusted for household size acoording to the modified OE CD scale (weights of 1.0 for head of household, .5 for each additional adult and .3 for each child). Italy and L ux embourg ould not be considered because L IS includes only data on net inoomes for these two countries.

Source: L IS; own calculations.

10 A large part of the total reduction of poverty rates is concentrated on one specific group of the population, the elderly. Pensioners usually have very high poverty rates before taxes and transfers, because of their low market income and reliance on public pensions. Hence, the impact of welfare state redistribution is very strong for this group. An international comparison of the redistributive impact of the welfare state may be biased by variations in age cohort structure. The reduction of poverty through the welfare states necessarily is higher in countries with a higher proportion of the elderly, all other things being equal. 
The empirical evidence suggests that welfare state redistribution indeed has a strong impact on poverty rates among prime-age households, yet there are marked variations across countries. Some clusters of countries can be identified: A high effectiveness of the welfare state in terms of poverty reduction is found in Belgium, Finland, Denmark and the United Kingdom. Whereas the first three of these countries also end up with low poverty rates for disposable incomes, the United Kingdom somewhat deviates from this pattern with medium poverty rates. ${ }^{11}$ An astonishing pattern of poverty reduction is also found in Sweden. Sweden achieves the highest reduction in absolute terms, but only a mediocre performance in relative terms, and ends up with fairly high poverty rates for disposable incomes. These startling results can partly be accounted for by a differing household definition. ${ }^{12}$

At the other end of the spectrum, a group of countries reduces poverty to a much smaller degree. The United States clearly stand out with a meagre reduction of poverty through transfers and taxes, cutting down poverty rates only by 3.4 percentage points (or 16 percent) from $21.6 \%$ to $18.2 \%$ of the population. With some distance, the Canadian, German and Australian welfare states also reduce poverty rates to a relatively small degree. Nevertheless, poverty rates after transfers and taxes are rather low in the German case, but must be attributed less to the redistributional impact of the welfare state rather than to a relatively good protection from poverty in the primary income distribution. In contrast, Canada and Australia show high poverty rates of more than one tenth of the prime-age population. 13

11 As in Mitchell's (1991) earlier study, the rank position of the United Kingdom is very sensitive to the poverty line chosen (not reported here).

12 However, the Swedish household definition leads to an overestimation of poverty among young adults and obviously has a strong impact on poverty rates of prime-age households. D eviating from the household definion of most other countries, the Swedish data consider all young adults from the age of 18 as separate households, even if they continue to live with their parents and are still economically dependent on them. Consequently, poverty rates tend to be higher than if a household definition more similar to that of other countries had been applied, but the size of this bias is not clear.

The Australian position in this rank order stands in a certain tension to Castles' and Mitchell's characterisation of the Ozeanian welfare states as belonging to a cluster of "radical welfare states" that are portrayed as countries that spend a relatively low share of national income on social transfers and services, but nevertheless achieve a high degree of income redistribution (Mitchell 1991; Castles/ Mitchell 1993). The results for the early 1990s put Australia closer to the bottom ranks than in Mitchell's (1991) earlier analysis, yet the distance to the United States is still apparent. 


\subsection{Welfare state effort and the alleviation of poverty}

What can explain different degrees of effectiveness of poverty alleviation? Are specific features of welfare states typically related to certain outcomes? In particular, is there a connection between welfare state effort and outcomes, in other words, are extensive welfare states more effective in alleviating poverty than the tighter ones? This section will assess the relationship between welfare state effort and poverty alleviation in two steps. Section 2.3.1 addresses the question of whether there is a correlation between the size of the welfare state and the incidence of poverty. Are high social expenditure rates associated with low poverty rates? Section 2.3.2 then turns to the reduction of poverty rates through taxes and transfers and its relationship to welfare effort.

\subsubsection{Welfare state effort and the incidence of poverty}

Using social expenditure as a proxy for welfare effort, the relationship between welfare state effort and outcomes in terms of poverty has been described in a fairly succinct way:

"The bigger the welfare state the smaller is the poverty rate" (Gustafsson/ Uusitalo 1990: 255)

Gustafsson and Uusitalo have based their statement on a regression of cash social expenditure (as a percentage of GDP) and poverty rates for the time around 1980. Their results suggest that social expenditure accounts for two thirds of the variation of poverty rates (Gustafsson/ Uusitalo 1990: 255). Förster (1994: 20-22) has found an even stronger correlation between welfare effort and poverty rates for families with children. More recent data confirm these results in principle for the prime-age population, although the correlation is less strong than in the earlier studies (see Chart 2). ${ }^{14}$ Pensions and other cash expenditure for the elderly has been excluded from the social expenditure ratios..$^{15}$

14 In contrast to those earlier studies, Chart 2 includes private mandatory social expenditure, but excludes expenditure on education; thus the results are not fully compatible.

15 To be sure, it would have been more accurate to exclude all social expenditure on the non-prime-age household population from this analysis since variations in socio-demographic structure obviously do no only have an effect on market income poverty rates and the redistributional impact of the welfare state, but also on the level of social expenditure. However, as aggregate data do not allow a detailed break-down of this kind, social expenditure ratios excluding old age cash benefits are taken as a proxy. 
Chart 2: $\quad$ W elfare state effort and the alleviation of poverty: Social ex penditure and relative poverty rates for primeage households in 0 E CD countries (head younger than 55 years)

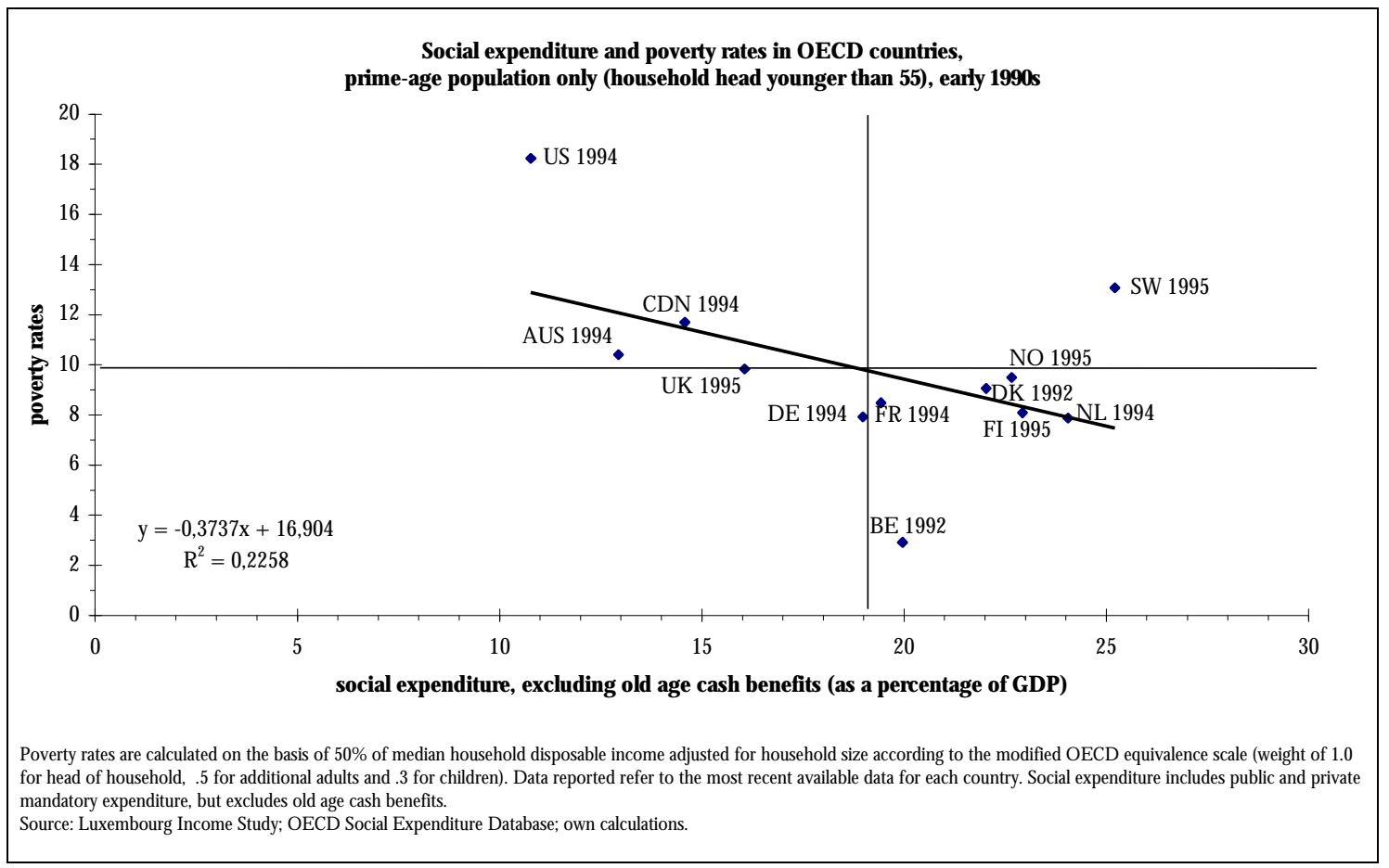

Chart 2 illustrates that there is in fact some correlation between social expenditure ratios and poverty rates. Countries with large social expenditure ratios tend to have lower poverty rates than countries with lower social expenditure ratios. Y et, social expenditure ratios only explain only somewhat more than one third of the variance in poverty rates. Some countries display much higher or lower poverty rates than what would have been expected on the basis of their level of social expenditure. Notably Belgium is very effective in this respect, to a lesser extent also Australia, France, Germany and the United Kingdom. In contrast, the United States and - with some methodological reservations - Sweden, as well as Norway are much less efficient.

However, this simple cross-sectional regression fails to fully elucidate the complex relationship between welfare state effort and the alleviation of poverty. The variation of poverty levels may also be determined by the primary income distribution, reflecting variations in socio-demographic and socio-economic structures. We would therefore expect that the size of welfare effort has a stronger impact on the reduction of poverty through welfare state redistribution rather than on the level of poverty as such. The following section 2.3.2 will address this question in more detail. 


\subsubsection{Welfare state effort and the redistributional impact of the welfare state}

As outlined above, the redistributional impact of the welfare state should also be exemplified by a clear correlation between welfare state effort and the reduction of poverty rates. Chart 3 below depicts the relationship between social expenditure and the reduction of poverty rates by welfare state redistribution for the prime-age population.

Chart 3: $\quad$ W elfare state effort and the alleviation of poverty: Social ex penditure and the reduction of poverty rates through transfers and tax es for primeage households in OE CD countries (head younger than 55 years)

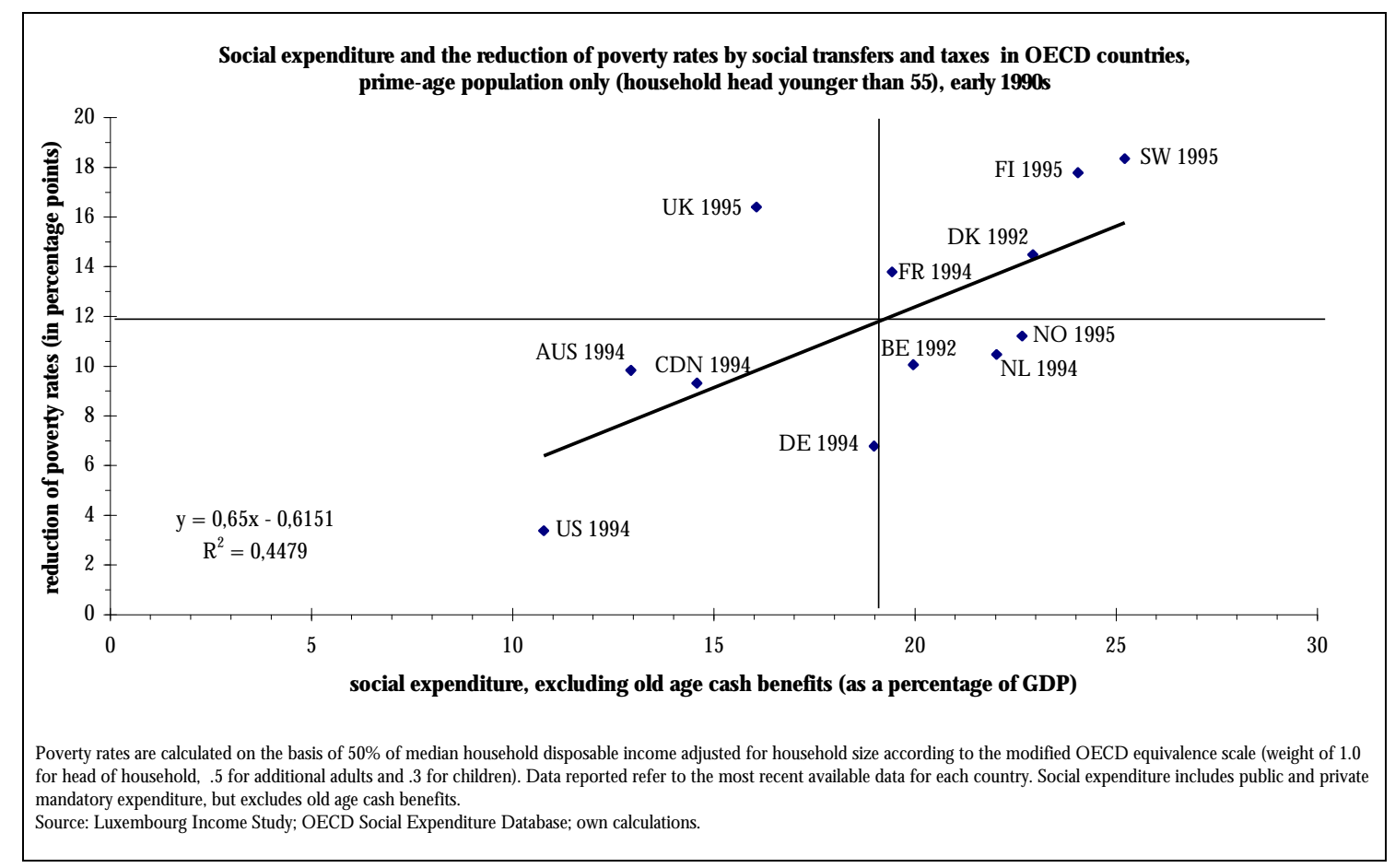

Indeed, Chart 3 indicates that countries with high social spending tend to reduce poverty more effectively than countries with a lower social expenditure ratio. Welfare effort is more closely correlated with the reduction of poverty rates than to the level of poverty as such (Chart 2, p. 9). This evidence suggests that the persistence of poverty in industrialised welfare states can partly be explained by the fact that countries do not spend enough on social transfers. Consequently, a further reduction of poverty rates could be best achieved by more extensive social expenditure according to this logic.

Nevertheless, countries scatter widely and display specific patterns of poverty alleviation. Relative to their level of social expenditure, the United Kingdom, and to a lesser extent also Finland, France and Australia were overproportionally effective in alleviating poverty. In contrast, the United States, Germany, Norway and the Netherlands achieve lower levels of 
poverty alleviation than what would have been expected on the basis of their social expenditure.

However, these simple regressions do not tell the whole story. There is large variation in the relationship between input (social expenditure) and output (reduction of poverty rates), hence, in the efficiency dimension. Countries with similar levels of social expenditure reach divergent levels of poverty reduction. For example, Germany, France and Belgium spend a comparable share of their GDP on social security for the prime-age population, yet their effectiveness in poverty reduction varies. Whereas France and Belgium are relatively successful in bringing down poverty rates, Germany is relatively inefficient in this respect and finds itself far below the regression line. In contrast, the United Kingdom is reaches a similar reduction of poverty rates as Finland or even Sweden, but on a markedly lower level of social expenditure. What can explain these large variations? Which factors can explain why some countries are more efficient than others in reducing poverty rates? Basically, these variations may be due to a number of substantial factors, including variations in policies, as well as differing socio-economic and socio-demographic contexts. The following section will elaborate further on this point.

\section{$3 \quad$ Assessing the effectiveness of social policies: unsolved puzzles and a possible solution}

\subsection{Limitations of the existing studies}

The review of the existing evidence on the redistributional impact of the welfare state has uncovered some interesting patterns, but has sketched a pretty crude picture of poverty alleviation. Welfare states face different degrees of external pressure, so the redistributional impact of the welfare state is dependent on socio-economic and socio-demographic conditions. Although the use of Beckerman ratios can mitigate this problem, certain flaws remain. In particular, variations in public-private mix may bias the measured effectiveness of the welfare state. Welfare states may achieve the same objectives in different ways, by regulative, distributive or redistributive policies associated with different levels of public in- 
volvement and levels of public spending. ${ }^{16}$ Although outcomes of these policies do not necessarily differ, Beckerman ratios will produce different results for the measured effectiveness in poverty alleviation. ${ }^{17}$

In addition, the measured effectiveness of social transfers fails to tell anything about the causes and the conditions of an effective alleviation of poverty. In particular, do institutional settings have an impact on an effective alleviation of poverty? O ur knowledge on the institutional conditions of effectiveness still is astonishingly sparse. This opinion is shared by Deborah Mitchell who concludes that most of the studies analysing outcomes of redistribution

„[...] arrive at a set of observations which observe what has happened in each country's transfer process without making clear how it had happened." (Mitchell 1991: 158, emphasis original)

Esping-Andersen takes the same line by stating that

"[...] why welfare state structures have such different distributional consequences is left largely unexplained. " (Esping-Andersen 1990: 56)

Beckerman ratios provide a very straightforward and efficient tool for evaluating the distributive effects of public policies and allow a relatively easy comparison of redistributional effectiveness over time and across countries, but this measure does not tell anything about the mechanisms of redistribution. The evaluation of the causes of a certain outcome in

16 This point relates to one critical limitation of Beckerman's method which exclusively focuses on the redistributional impact of actual taxes and transfers, but ignores the fact that the primary distribution of income is not independent of the welfare state. The counterfactual of an income distribution without transfers is nothing more than a fiction that assumes that the welfare state has a merely direct effect on the distribution of income. This is, however, not necessarily the case, since individual expectations and behaviour are also reflected in the primary income distribution. Taxes and transfers may have an impact on the supply of and the demand for labour, because they provide alternative sources of income other than wages from employment. In addition, people may change their behaviour in terms of saving and consumption patterns. For example, if people expect generous pensions from a public pension scheme, they may deem it unnecessary to contribute to a private pension plan (cf. Mitchell 1991: 43-36). Björklund (1998: 46-47) even goes one step further in claiming that a complete economic model of the redistributional impact of the welfare state should even consider changes in mating, fertility and divorce behaviour.

17 One example for similar outcomes of different welfare state strategies can be found in pension systems. Although some countries have chosen to organise a large part of their system of old-age income security in terms of occupational pensions provided by private bodies, redistributional effects are hardly distinguishable from public pension schemes, largely because of a strict regulation and supervision of private pension schemes in some countries (cf. Pedersen 1999; Behrendt 2000b). It is therefore questionable whether the focus on public redistribution leads to adequate results for an evaluation of the impact of the welfare state. 
terms of income distribution or poverty requires a detailed assessment of a country's institutional framework that structures redistribution. ${ }^{18}$

Being interested in the question of why welfare states fail to effectively alleviate poverty, a closer evaluation of the bottom safety net of the welfare state promises useful insights. In modern welfare states, the ultimate responsibility for the alleviation of poverty is given to social assistance schemes and other minimum income schemes. These schemes form the basic net of the welfare state and are ultimately responsible for the alleviation of poverty. If this net does not hold, the effectiveness of the welfare state as a whole is fundamentally challenged.

\subsection{Focussing on the basic safety net of the welfare state}

As the basic safety net of the welfare state, minimum income schemes play a decisive role for the alleviation of poverty. 19 We would expect that minimum income benefits form an income ceiling below which no individual or household should fall (cf. Veit-Wilson 1998). These schemes step in if the primary income distribution and social insurance schemes fail to provide a decent income level. However, the persistence of poverty in industrial welfare states suggests that this basic safety net of the welfare state fails to achieve this goal, as a sizeable proportion of the population appear to fall through this safety net and find themselves in poverty. By this token, the persistence of poverty in industrial welfare states may eventually be explained by a failure of minimum income schemes.

If minimum income schemes play a decisive role for the alleviation of poverty in industrial welfare states, our focus of analysis should shift from the welfare state as a whole to its basic safety net. A thorough analysis of these schemes can offer some more insights into the causal patterns of poverty alleviation in industrial welfare states, and can help to solve some of the puzzles that are still present in poverty research. In particular, this approach can shed some more light on the mechanisms that are responsible for the fact that a re-

18 This point is well exemplified in the following statement: „It is a sad reflection that after twenty years of unprecedented economic growth and massive government expenditure in social security, poverty is still prevalent in all EEC countries. Economic growth and increased public expenditure do not by themselves reduce inequalities and abolish poverty. Governments need to implement explicitly designed policies to achieve such ends." (G eorge/ Lawson 1980: xi-xii)

19 The Commission of the European Communities recently has again emphasised the role of minimum income benefit schemes. One of the goals of a reform of social protection in the European Union is to "ensure effective safety nets, consisting of minimum income benefits and accompanying provisions, with a view to efficiently combat poverty and exclusion of individuals and families" (European Commission 1999: 14). 
markable proportion of the population finds itself in income poverty. Variations in the effectiveness of poverty alleviation may be explained by the performance of the basic safety net of the welfare state.

In spite of their importance for the alleviation of poverty, social assistance schemes have rarely ever stood in the focus of the mainstream of comparative welfare state analysis. Most major studies have addressed social insurance schemes while social assistance was considered as a relict of the old poor law tradition that would subsequently be eliminated with the maturing of social insurance schemes (cf. Atkinson 1999: 3). Nevertheless, these expectations have not been fulfilled; social assistance schemes still make up - and always have made up - a considerable portion of social expenditure in Western European welfare states. O nly in recent years, rising expenditure on social assistance in a time of persistent mass unemployment in many Western European welfare states appears to have attracted the interest of comparative welfare state research towards social assistance schemes and other minimum income schemes. A number of large-scale reports have sought to systematically compare the institutional design of minimum income schemes in industrialised countries (Eardley et al. 1996a, 1996b; Guibentif/ Bouget 1997; OECD 1998a, 1998b, 1999).

Not only comparative welfare state research has underestimated the role of minimum income schemes, but also poverty research showed little interest in these schemes. ${ }^{20} \mathrm{Al}$ though social assistance schemes are explicitly aimed at alleviating poverty, poverty research has seldom thoroughly assessed the relationship between minimum income schemes and poverty. When assessing the causes of poverty, poverty research largely has scrutinised factors to be found in the distribution of earnings, the labour market, in the social structure, and also social transfers for specific groups of the population, yet often neglected the basic safety net of the welfare state. The incidence of poverty in advanced welfare states seems to have been attributed to a general mismatch of concepts of poverty and societal minimum income standards embodied in these schemes. While some observers appear to have tacitly assumed that social assistance benefits are too stingy as to provide a sufficient protection from poverty, others have rather sought the causes of this discrepancy in the measurement of poverty. Especially the widely-used relative poverty line of 50\% of median

20 For example, this is exemplified by the fact that the recently published „International Glossary of Poverty” devotes only the following passage to social assistance schemes: „Social assistance consists of relief for those who are poorest, in cash or in kind [...]. Social assistance is usually subject to some kind of means-testing and may be subject to administrative or professional discretion." (Gordon/ Spicker 1999: 121; emphasis omitted). 
equivalent disposable income has been criticised as reflecting income inequality rather than a standard of subsistence, thus overstating poverty in rich countries (cf. Krämer 1997, 2000; Blackburn 1998).

Indeed, a large proportion of private households are poor even if they have received any social assistance benefits or other means-tested benefit (cf. Kangas/ Ritakallio 1998a; Behrendt 2000a). The suspiciously small overlapping between of social assistance receipt and poverty has often been interpreted as an indicator for flaws of income as an indicator for poverty (cf. Halleröd 1991; Kangas/ Ritakallio 1998a). Possible reasons for a flawed measurement of income poverty could be that low-income strata are not adequately represented in income surveys, that they tend to have higher non-response rates than other groups of the population, and that many households do not properly report their income, especially income from means-tested benefits that are of particular relevance here (cf. Atkinson et al. 1995). ${ }^{21}$

The lack of knowledge about the relationship between minimum income schemes and poverty is only one example of a more general deficit. Whereas comparative social policy research has extensively analysed the genesis and institutional similarities and differences of social security schemes, research into the outcome dimension is still underdeveloped. In particular, only a small number of studies have systematically evaluated the quality of social security schemes in a comparative perspective (cf. Dixon 1999).

The following chapter will shift the focus of analysis from the welfare state as a whole to its basic safety net in order to shed more light on these patterns of poverty alleviation and will eventually come up with a tentative explanation for these patterns.

\section{$4 \quad$ The basic safety net of the welfare state and its effects on the alleviation of poverty: Evidence from Britain, Germany and Swe- den}

An alternative approach can help to contribute to the explanation of the incidence and the causes of poverty in industrialised welfare states. This approach confronts the evidence from survey data with the institutional regulations in each countries in order to cross-check the quality of the data, and to come up with some institutional explanations for the apparent ineffectiveness of the welfare state.

21 A fully-fledged discussion of these points can be found in Behrendt (2000c). 
What can explain this apparent failure of the basic safety net of the welfare state? Basically, this shortfall may be due to three factors: eligibility, adequacy of benefits, and take-up by the eligible population. Let us assume that a household (or person) is in need because of an insufficient market income and/ or insufficient social transfers. Need is defined as an inadequate level of resources that does not allow a decent standard of living. At this stage, the redistributional impact of the welfare state exclusively depends on social assistance scheme since all other potential income sources are exhausted. Once the social assistance scheme comes into play, a three-stage process determines whether this household can effectively protected from being poor or not. First, effectiveness depends on the question whether the person or household is actually entitled to receive social assistance (eligibility). If the household is entitled to receive benefits from social assistance, the second dimension of effectiveness becomes relevant: benefits must be generous enough as to cover the needs of the household (adequacy). If benefits are not adequate, poverty cannot be effectively alleviated by social assistance, the household stays poor. Finally, households can only be effectively protected from poverty if benefits are actually claimed by the household in need (take-up). If this is not the case, the household will stay poor even if the first two conditions are met. The sequence of these three conditions is shown in Chart 4 below.

Chart 4: Social assistance schemes and an effective alleviation of poverty: A simplified model

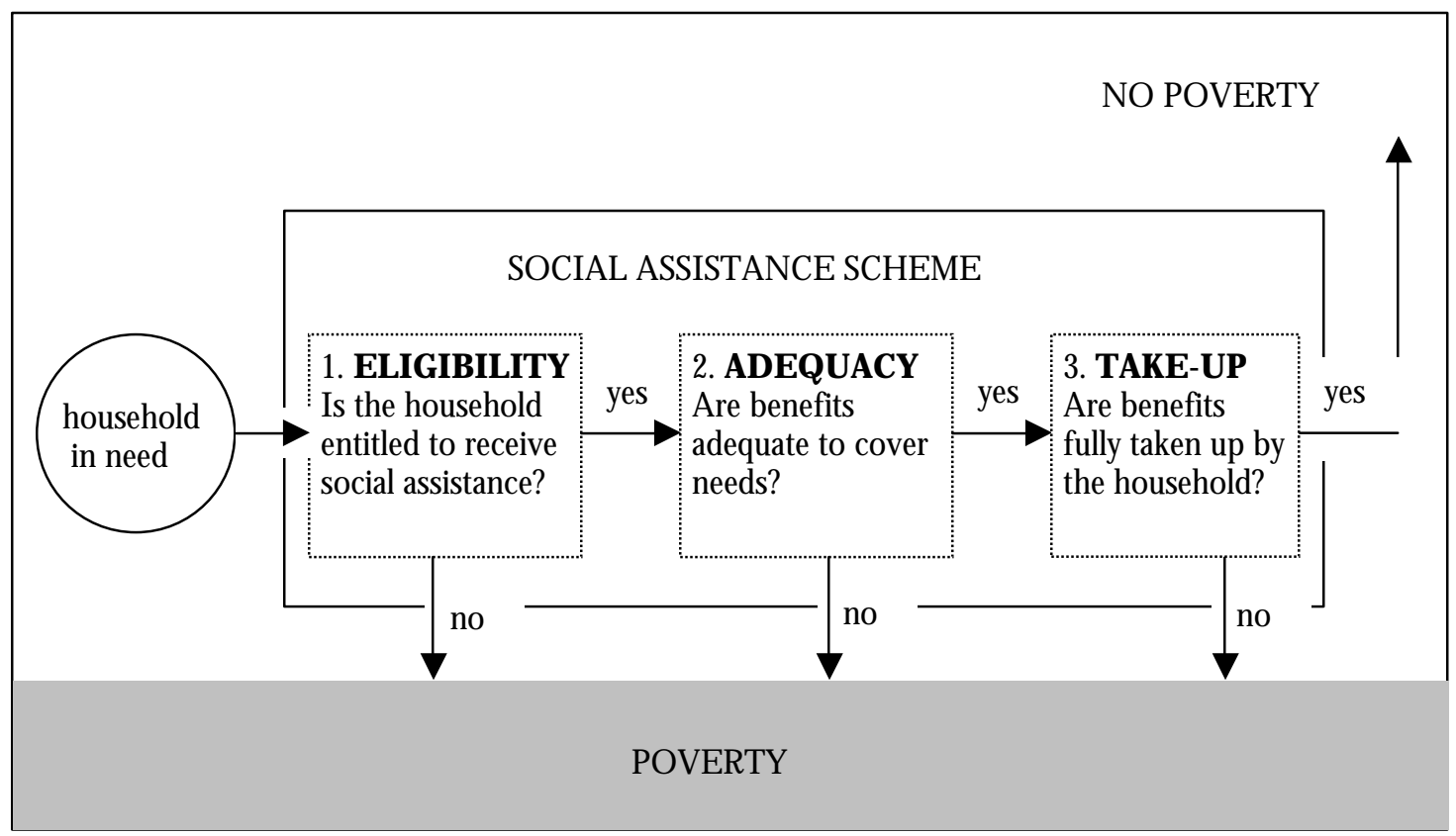

The following sections will scrutinize these three conditions of effectiveness for three West European countries - Britain, Germany, Sweden -, largely drawing on the results of a 
larger research project (Behrendt 2000c). These three countries have often been considered as „paradigmatic” cases for three distinct „welfare state regimes”. Comparative welfare state research has often used typologies as a shorthand to describe institutional similarities and differences of modern welfare states (e.g. Titmuss 1974; Esping-Andersen 1990, 1999). Attempts to establish typologies of minimum income schemes on the basis of their institutional characteristics have also positioned these countries in different clusters (Eardley et al. 1996a; Leibfried 1992; Lødemel/ Schulte 1992).22 The Swedish socialbidrag scheme is characterised by a marked division of social assistance and social insurance, as social assistance is administrated at the communal level with a high level of administrative discretion and a strong emphasis on social work treatment. In contrast, the British income support is closely integrated with non-means-tested social insurance benefits, administrated at the central government level, with strong entitlements and a high degree of standardisation. The G erman Sozialhilfe operates with a medium degree of division between social insurance and social assistance. Rights positions and administrative discretion are balanced, as is the involvement of central and local units in the regulation and administration of social assistance.

These three countries are also characterised by a specific profiles of poverty and poverty alleviation. Sweden and the United Kingdom display similar poverty rates at the 50\% level, yet their poverty profiles are very different. Sweden exhibits a markedly higher proportion of extreme poverty, whereas the poor in Britain are dominated by households living in moderate poverty. The German welfare state surprises with relatively low poverty rates, although being notorious for a low amount of vertical redistribution of income and lacking minimum income elements outside of social assistance.

\subsection{Eligibility}

The first condition of effectiveness, eligibility, cannot contribute much to the explanation of poverty in these three countries (cf. Behrendt 2000c). Social assistance schemes are virtually universal in each of the three contries considered while only small groups of the population are excluded from general social assistance schemes. This applies in particular to some categories of recent migrants, but as these groups are unlikely to be included in the

22 However, Eardley et al. (1996a) group Germany together with „Beveridgean“ welfare states such as the United Kingdom and Ireland in the category of "welfare states with integrated safety nets", yet they concede that the classification of Germany poses some problems and propose to regard Germany as a „bridge“ to the „dual social assistance“ type (Eardley et al. 1996a: 169, footnote 13). 
sample that is used for the calculation of poverty rates, their exclusion cannot explain the incidence of poverty. ${ }^{23}$

\section{$4.2 \quad$ Adequacy}

The second condition of an effective alleviation of poverty, the adequacy of social assistance benefits, offers some more guidance on this question. Are benefit levels high enough as to guarantee an effective protection from poverty?

Social assistance entitlement levels are evaluated on on the basis of model calculations that allow to keep the need level of the household constant and thus permit an informed comparison of social assistance entitlements across countries. Basically, this approach defines a number of model households with specified needs. ${ }^{24}$ We can then assess the entitlements to social assistance the families would have in each of the countries considered. However, the choice of household types to be assessed invariably involves a certain degree of arbitrariness and is far from satisfactory reflecting the actual variation of household types in the real world. The circumstances of these model households have to be specified in detail in order to enhance the precision of the comparison across countries. However, the more specifically are the characteristics of model households, the less representative are these for the whole population.

23 These groups may be eligible to some specialised social assistance benefits for migrants or urgent payments, but as benefit levels are lower than in the general scheme, these programmes do not guarantee the same level of protection from poverty.

24 In order to keep the household need level constant across countries, this method requires the definition of model households. The more detailed the definition of model households, the less representative are the chosen model households for the recipient population. Thus, the definition of model households inevitably has to balance precision and representativity. 
Following Eardley et al. (1996a), thirteen model households have been chosen for this study. ${ }^{25}$ The following household types are used for the computation of social assistance entitlements. ${ }^{26}$
A.Single person (35 years)
B.Single person (68 years)
C.Couple (both 35)
D.Couple (both 68)
E.Couple (both 35) with child (2)
F.Couple (both 35) with child (7)
G.Couple (both 35) with two children $(7,14)$
H.Couple (both 35) with three children $(4,7,14)$
I.Couple (both 35) with four children $(4,7,10,14)$
J.Single parent (35) with child (2)
K.Single parent (35) with child (7)
L.Single parent (35) with two children $(2,7)$
M.Single parent (35) with two children $(4,7)$
N.Single parent (35) with two children $(7,14)$

The family types with a child aged 2 years (household types E, J and L) are chosen to account for a peculiarity of the $G$ erman social assistance scheme which permits a full income disregard of parent allowance (E rziehungsgeld) and thus considerable improves the income situation for many parents with young children under three years. The level of social assistance without any claims for parent allowance is reflected in the model families with children aged 7 (household types F, K and M) who are entitled to exactly the same amount of social assistance except for the parent allowance.

For each of these model families, social assistance entitlements have been calculated on the basis of institutional regulations, including the standard benefit rate, premiums for special

25 The choice of model households closely sticks to the methodology of Eardley et al. (1996a) in order to ensure comparability with their results. Some small changes have been made, however. Their model families have been supplemented by four new household types because of their relevance for current discussions on poverty. Since large families with three or more children run a overproportionate risk to claim social assistance and to be poor in every one of the three countries, two additional households with three and four children have been added (household types $\mathrm{H}$ and I). Two more types of single parent families have been included in order to include the German parent allowance (E rzie hunosgeld) into the calculation of benefit packages. The parent allowance scheme grants a monthly payment of DEM 600 (EUR 307, as of 2000) to parents of young children provided that one partner working less than 19 hours per week or not working at all in order to take care of the child. The national parent allowance is available for two years, yet some federal states provide complementary schemes for up to one additional year. These state benefit schemes are also fully disregarded for the calculation of social assistance. After six months, the benefit is means-tested.

26 As social assistance benefits may markedly vary with the age of household members, different ages of adults and children are assumed. 
needs, one-off benefits and housing allowances. This benefit package constitutes an effective minimum income standard for the majority of the population (cf. Veit-Wilson 1998). A detailed description of the method of calculation can be found in the Appendix.

In order to evaluate the adequacy of social assistance benefits for the alleviation of poverty, the level of social assistance entitlements of these model households can be easily compared to the minimum income level as defined by a relative poverty line. If poverty is defined as 50\% of median equivalence income, do minimum income benefits bring people out of poverty?27 Which income level do recipients of social assistance reach relative to the general income level in the society in which they live?

Chart 5 displays the level of social assistance entitlements after housing cost as a proportion of median income for Britain 1995, and illustrates the relationship of social assistance benefits after housing cost to the poverty line. This allows the evaluation of the question whether social assistance entitlements would bring the model households the poverty line. Since the actual entitlement of households may vary depending to individual circumstances and divergent rent levels, the chart includes an error indicator that allows for a scope of $10 \%$ in each direction.

27 As for the poverty rates presented above, a poverty line of $50 \%$ of median equivalent household income has been computed on the basis of LIS data. The calculations of the poverty line and the equivalent income of model household are also based on the modified OECD equivalence scale. Whereas the absolute value of the benefit packages presented in model calculations presented in Chart A-1 in the appendix refers to the year 1995 for reasons of comparability, the German data in this section refer to 1994 because newer LIS data are not available. 
Chart 5: $\quad$ L evel of social assistance entitlements in \% of median income, Britain 1995

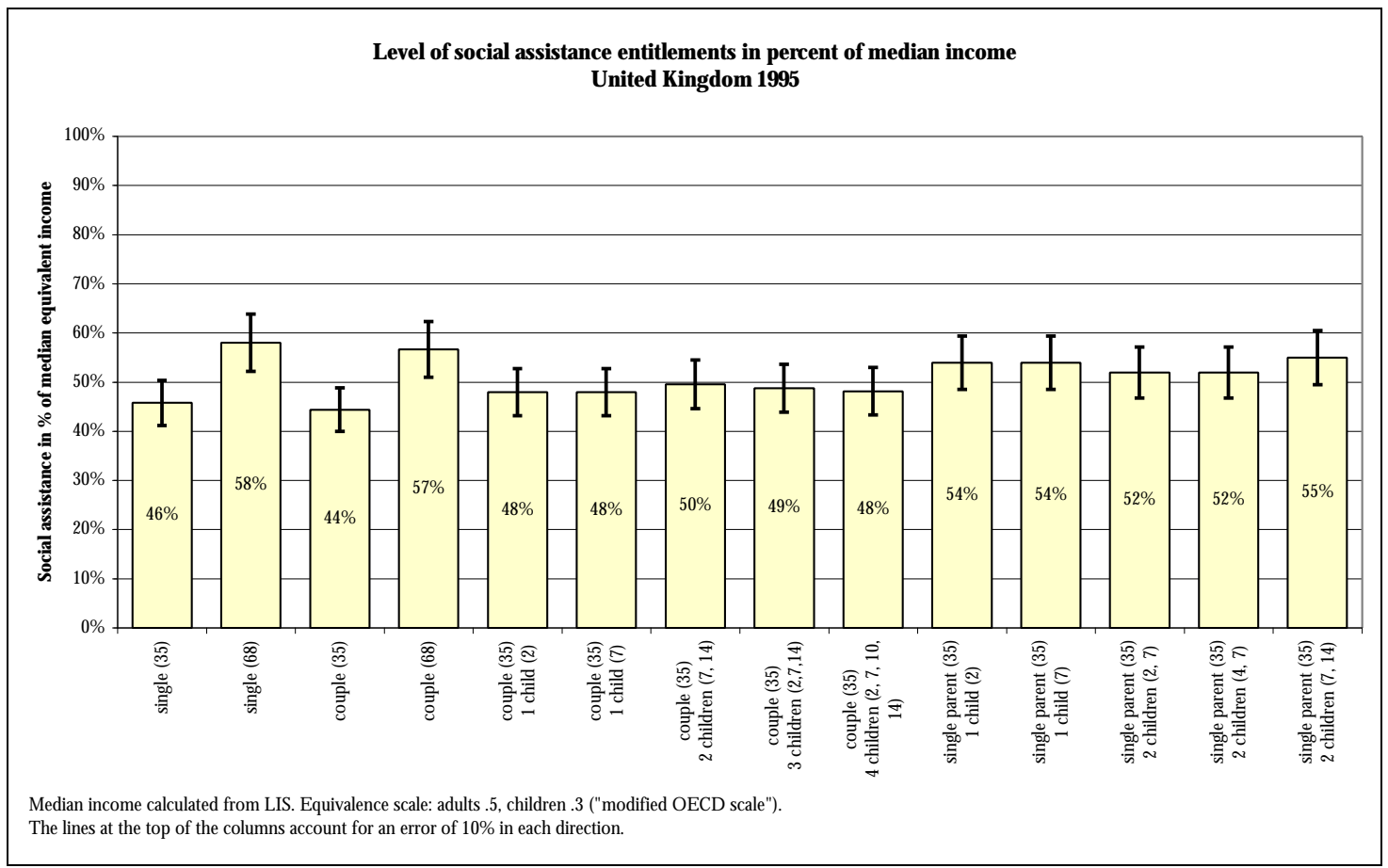

For the model households specified above, the British social assistance provides an income level of between $44 \%$ and $58 \%$ of median income. Only the households of the elderly and single parents are brought above a poverty line of $50 \%$ of median income, whereas childless working-age households and two-adult families with children have an income lower than the $50 \%$ income standard, with the only exception of a two-parent family with two children exactly matching the $50 \%$ level. None of these model households falls below the 40\%-poverty line, though. Interestingly, the preferential treatment of the elderly and single parents exactly mirrors the liberal idea that the welfare state should comfort people whose earnings capacity is limited (by old age or caring responsibilities), while only providing a basic minimum income for less vulnerable groups. 
Chart 6: $\quad$ L evel of social assistance entitlements in \% of median income, G ermany 1994

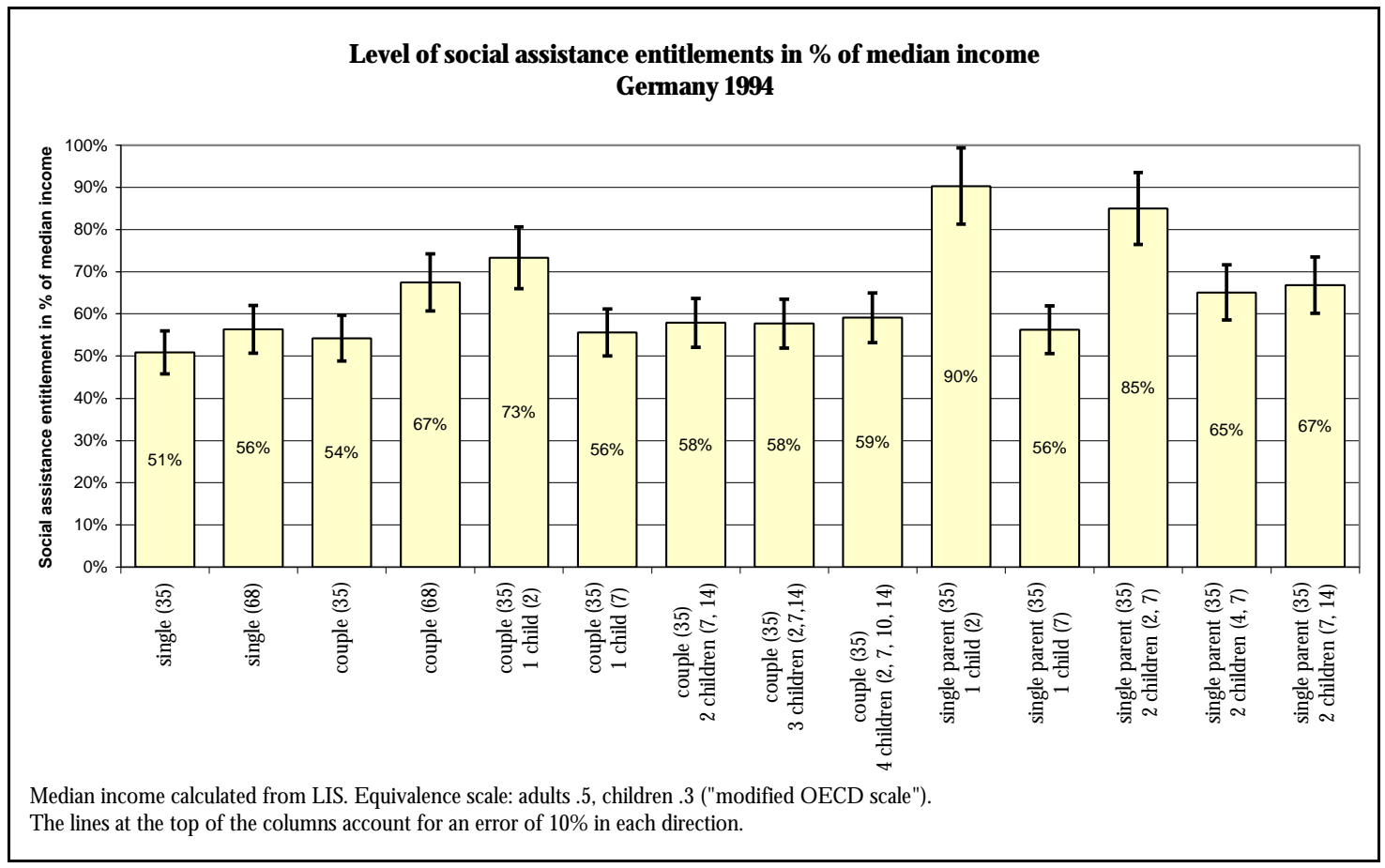

For Germany 1994, social assistance entitlements provide an effective protection from poverty for each of the model households (Chart 6 above). The level of social assistance varies from $51 \%$ of median income to $67 \%$ of median income, or even to $90 \%$ for families with young children receiving parent allowance. The combination of parent allowance and social assistance offers a very generous level of support for families with young children. Even families who do not receive any parent allowance (see corresponding household types with older children) still reach an income level above the 50\%-poverty line, yet their income position is relatively bad compared to the other family types. Relatively well-off are elderly couples, families with several children and single parents, whereas especially prime age singles and couples have to live on a rather stingy benefit level. Nevertheless, none of the model families used in this comparison can be considered as poor at the $50 \%$-level.

Overall, the German social assistance scheme appears to provide for a fairly generous benefit level that would allow model households to find their way out of poverty. Benefit levels are not particularly generous, so most model households reach an income level of shortly above $50 \%$ of median equivalent income. Similarly to the British case, the elderly and single parents enjoy a more generous benefit level than prime-age households, and parents with small children receiving the parents' allowance will even reach a more comfortable income level well above the $60 \%$-poverty line. 
Chart 7: $\quad$ L evel of social assistance entitlements in percent of median income, Sweden 1995

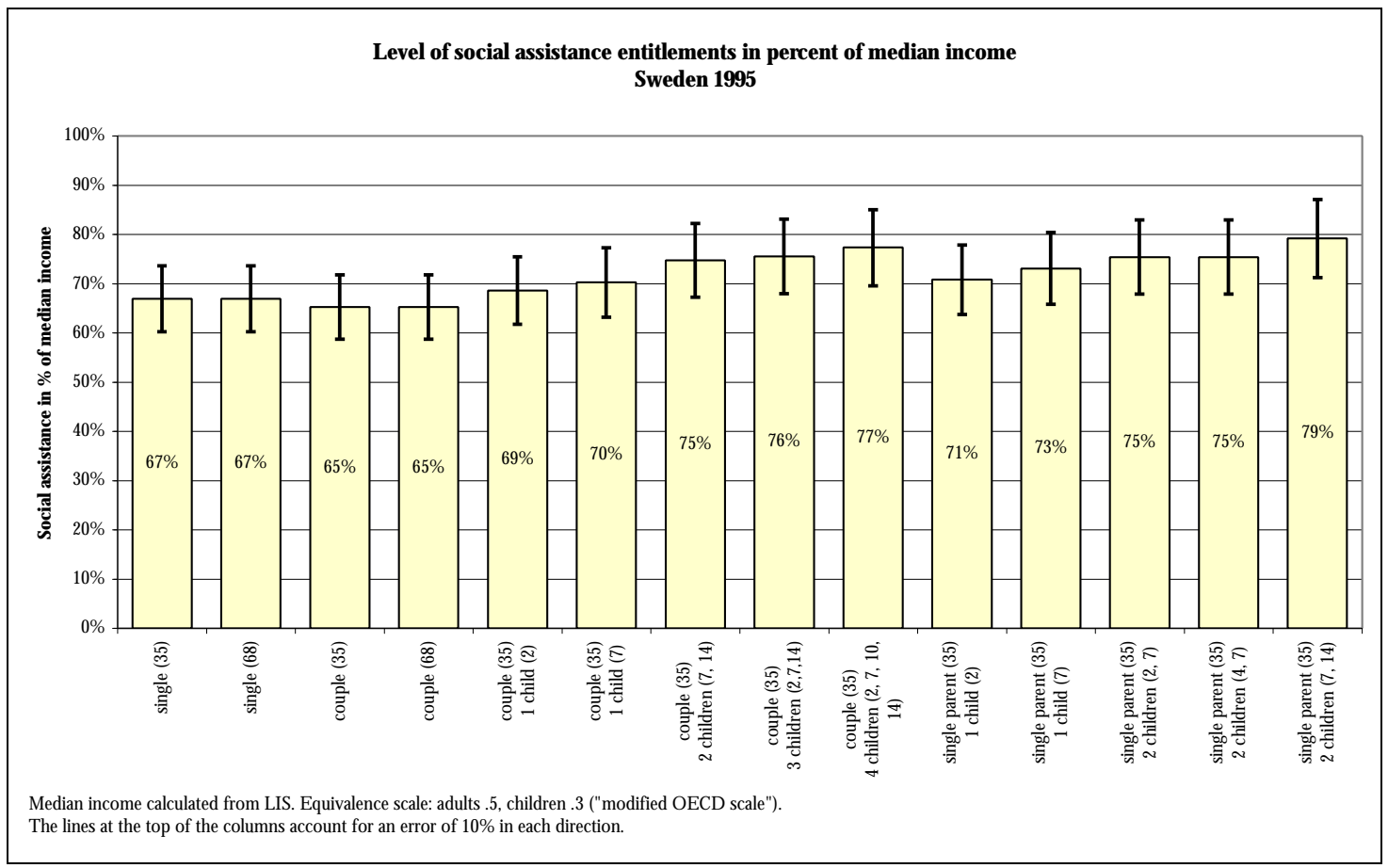

The Swedish social assistance offers a more uniform pattern that appears to provide for a decent standard of living. Each of the model families is brought even above the $60 \%$ poverty line, some even enjoy an income position of more than $70 \%$ of median income. Moreover, there seems to be a strong relationship between the size of the household and the level of provision, the larger the family, the more generous are the benefits. ${ }^{28}$ Benefit rates may however be slightly overstated since the rent level used in the calculations refers to the capital of Stockholm whereas the average rent level is somewhat lower. In addition, claimants are required to pay a higher share of housing costs other than the rent out of their standard benefit rate than in the other two countries (cf. Eardley et al. 1996a: 109139). However, even if the rent level was markedly reduced, the Swedish social assistance scheme would still bring households over the $50 \%$-poverty line. ${ }^{29}$

28 This effect must be accounted to the fact that the institutional equivalence scales that are embodied in the social assistance scheme attach a larger weight to children than does the modified OECD equivalence scale that has been used in Chart 7.

29 It should be remembered that the benefit rates shown in Chart 7 refer to the benefit rates as recommended by the government whereas actual benefit rates as applied on the municipal level may markedly diverge. The recommended rates shown above can only provide some general guidance on the benefit level rather than a accurate reflection of reality. 
The previous discussion of the adequacy of standard benefit rates has illustrated that the relationship between the level of social assistance and the alleviation of poverty is very complex. Even a sophisticated calculation of benefit packages still cannot fully reflect the complexity of social assistance payments. Yet, we can identify some patterns of benefit structure in the three countries on the basis of the model household approach. Sweden provides for the most generous level of social assistance benefits that does not only lift the model households out of poverty, but offers a comfortable income position even above the near poverty bracket ( $60 \%$ poverty line). The second rank is taken by Germany that is characterised by a strong variation of benefit rates depending on the household circumstances, yet all model households are brought over the poverty line. Britain is the only country for which the model household approach testifies inadequacy. For some workingage households, benefits are not sufficient to bring them above the poverty line. O nly the elderly, and to some degree also single parent households can expect adequate social assistance benefits.

However, these conclusions have to be qualified, again considering the underlying methodological assumptions of this study. The simulation was based on the assumption that every household is eligible for social assistance benefits, and actually realizes its entitlement. Whereas the first assumption supposedly only has a negligible impact on measured poverty rates, the second one is more problematic. Empirical studies show that a marked proportion of households do not claim their social assistance benefits for a number of reasons. At this stage, the last condition of take-up comes into play.

\subsection{Take-up}

Even if social assistance schemes cover the entire population and guarantee an adequate benefit, poverty may still occur if benefits are not claimed by those who are eligible to receive them. Unlike for the first two conditions, eligibility and adequacy, public policies only have a limited influence on the question of take-up, as the process of claiming cannot entirely be controlled by the state. Ultimately, the question of take-up is largely governed by individual actions on the part of potential claimants, but individual perceptions and behaviour are strongly influenced by public policies. There is a broad array of possible causes of non-take-up that relate to a direct or indirect impact of public policies onto non-take-up (Corden 1995). Basically, three factors can hamper take-up, each closely associated with public policies. First, people may not be aware of benefits available and their entitlement to these benefits (ignorance). Second, claimants may fear stigmatisation when claiming benefits (stigma). Finally, social assistance regulations and the claiming process may be fash- 
ioned in a way that impedes the full take-up of benefits (complexity) (cf. Deacon/ Bradshaw 1983: 122-149).

Although there is hardly any comparable evidence on the extent of non-take-up in the three countries considered, we can quite safely conclude from a comparison of national studies that $15-20 \%$ of private households do not realize their claim in the United Kingdom, as do some 40-50\% in Germany, and possibly as many in Sweden where this kind of studies is virtually unknown (cf. van O orschot 1991, 1995, 1998; Behrendt 2000c).

Britain is not only the country with the strongest concern about non-take-up and the best empirical evidence on this issue, but also seems to have the least problem of non-take-up. What does account for this large difference? Can institutional settings, such as the general programme structure and the administration of social assistance, account for this fact? The following factors have been found to be particularly relevant:

First, the British social assistance scheme is organised in a more standardised way than in Germany and Sweden, with several implications for the take-up of benefits. As the programme structure is rather simple, based on national regulations without regional variations in benefit rates and administered at the national level, information on the availability of benefits and eligibility conditions is more easily disseminated than in the fragmented and more complex benefit schemes in G ermany and Sweden. As leaflets and claiming forms for social assistance are accessible at every post office and at every branch of the Benefit Agency, potential claimants can easily obtain the necessary information about their entitlement. In addition, the administrative integration of income support with other social security benefits possibly leads to a higher familiarity with eligibility conditions on the part of social security officers, and makes it easier to complement insufficient incomes by income support.

Second, take-up is expected to be high where social assistance is considered as an individual right rather than something to be granted on a discretionary or charity basis. Entitlements are very strong in Britain; social assistance is highly regulated and the administration of social assistance largely parallels the administration of non-means-tested social security benefits. In terms of administrative procedures, it does not make much of a difference to claim a pension or income support in Britain while the gap between non-means-tested and means-tested benefits is much larger in Germany and Sweden. In terms of administrative routines, notably the scope of administrative discretion is assumed to have a negative effect on take-up rates since it often involves time-consuming application procedures and intensive checks of the claimant's situation that may be perceived as stigmatising. In addition, 
discretionary decisions of social assistance officers may be more strongly subject to flawed results than more standardised routines. In Britain, only the social fund provides a discretionary element, yet the significance of this scheme is relatively small. Discretion at the local level is much stronger in Sweden, where municipalities have a say in benefit rates, yet limited by jurisdiction. The German social assistance scheme is governed by national framework legislation, and benefit rates hardly vary across federal states. Yet, there is some scope of administrative discretion in granting one-off benefits.

Third, the rights-based character of the British social assistance is also supported by the relatively generous exemptions for earned income and assets, whereas means-tests in Sweden are much stricter, not allowing for any income disregards. In a way, the design of the Swedish social assistance requires claimants to be „poorer” than in Britain before granting any benefits. The Swedish social assistance is much more strongly grounded in a poor law tradition than the British scheme, and the internal division of the welfare state into social insurance and social assistance is much more pronounced. Germany appears to be situated once again in a middle position, with relatively strong institutionalisation of individual rights, yet with some degree of administrative discretion.

Fourth, the rules about liability of the extended family in the German social assistance schemes are assumed to have a detrimental effect on take-up. There is strong evidence that many people abstain from claiming social assistance because they fear that their relatives will made liable for any social assistance payment. Although this rule is hardly ever applied because of generous income disregards and the general suspension of this rule in some federal states, many people seem to refrain from claiming because they are not aware of these exemptions or because they do not want that the test of their relatives' income situation uncovers their own financial situation to their relatives, even if those would not have to pay. O nly the $\mathrm{G}$ erman social assistance scheme entails such a regulation of family liability, whereas the British and the Swedish schemes do not require contributions by members of the extended family.

By and large, the institutional structure of the British social assistance schemes seems to be structured in a way that incorporates relatively few obstacles to claiming benefits in comparison to Germany and Sweden. The markedly higher non-take-up rates in the latter two countries suggest that potential claimants face more serious impediments, possibly to be found in the less readily available information on the availability of benefits and entitlement rules. In addition, the very strict means-tests in Sweden and the liability of the wider family in G ermany may also contribute to higher non-take-up rates in these countries. 


\section{Conclusion}

The evidence presented for the three countries of Britain, Germany and Sweden has shown that an assessment of the institutional framework can help to explain the incidence and the causes of poverty in highly-developed welfare states. Especially minimum income schemes play a decisive role for the alleviation of poverty. The evaluation of their effectiveness in the dimensions eligibility, adequacy and take-up has uncovered specific national patterns of poverty allevation.

For the United Kingdom, there is some evidence that the incidence of poverty is closely associated with a relatively low benefit level that does not bring poor households over the $50 \%$ poverty line. However, in relation to a lower poverty line of $40 \%$, the alleviation of poverty is very effective, as the small amount of extreme and severe poverty shows (Chart 1, p. 3). This finding can be related to the fact that take-up rates are relatively high. In contrast, the Swedish social assistance scheme offers a very high benefit level (yet with large local variation) that guarantees an effective allevation of poverty for all household types considered. However, only a small proportion of the eligible population seems to claim benefits. O ne reason for the supposedly low take-up rates are the very strict means-tests in the Swedish social assistance scheme. This illustrates two opposing strategies of poverty alleviation in the two countries. Whereas Sweden offers a very generous benefit level but operates with a number of hurdles that are supposed to be overcome only by the "truly needy", the United Kingdom has established a scheme that is more easily accessible, but guarantees a rather mean standard of living. Germany once more finds itself between these two extremes. Benefits almost exactly match the poverty line, so most households should be brought out of poverty. However, as the calculations operate with some assumptions that make the calculation of benefit levels not very robust, it may well be that some households actually will remain slightly below the poverty line. A low take-up rate also contributes to the explanation of poverty, partly spurred by the family liability regulations. These results may also contribute to the explanation of different patterns in the reduction of poverty rates found in Chart 3 (p. 10), where the United Kingdom stands out with an extraordinarily high degree of effectiveness in relation to her level of spending, while Germany was much less successful in reducing poverty.

The patterns of poverty alleviation identified in the three case studies illustrate different stories hide behind seemingly similar poverty rates. A closer analysis of the basic safety net of the welfare state can help to uncover the mechanisms of poverty alleviation and can provide some guidance for future reforms. In order to mend the "holes" in their safety 
nets, the United Kingdom would have to increase benefit levels, while Germany and Sweden should rather inspect the organisation and administration of social assistance and remove barriers to take-up, possibly through a closer integration of minimum income benefits with other social security schemes and more transparent administrative procedures. By this token, welfare states could have a much more successful record in poverty allevation, provided that problems in the measurement of poverty can also be solved (but this is another story).

The paper has shown that an evaluation of welfare state outcomes in terms of poverty allevation should look behind easily accessible aggregate data like social expenditure ratios and Beckerman ratios, as these are often subject to serious methodological limitations. Confronting this evidence with information about the institutional framework in each country can yield much more satisfactory and stimulating results. 


\section{References}

Atkinson, Anthony B. (1999): The E conomic Consequenoes of Rolling Back the W elfare State, Cambridge (Mass.): MIT Press.

Atkinson, Anthony B./ Rainwater, Lee/ Smeeding, Timothy M. (1995): Income D istribution in OE CD C ountries: E vidence from the L ux embourg Income Study, Paris: OECD .

Beckerman, Wilfred (1979): The impact of income maintenance programmes on poverty in Britain, E conomic Journal 89: 261-279.

Behrendt, Christina (2000a): Do means-tested transfers alleviate poverty? Evidence on Germany, Sweden and the United Kingdom from the Luxembourg Income Study, Journal of E uropean Social Policy 10 (1): 23-41.

Behrendt, Christina (2000b): Private pensions - a viable alternative? Their distributive effects in a comparative perspective, International Social Seaurity Review 53 (3): 3-26.

Behrendt, Christina (2000c): A Safeguard A gainst Poverty? A n A nalysis of the E ffectiveness of Social A ssistanœ Schemes in A lleviating Poverty in Germany, Sweden and the United Kingdom Based on L IS D ata, Konstanz: Universität Konstanz, mimeo.

Björklund, Anders (1998): Income distribution in Sweden: what is the achievement of the welfare state?, Swedish E conomic Policy Review 5: 39-80.

Blackburn, McKinley L. (1998): The sensitivity of international poverty line comparisons, Review of Income and W ealth 44 (4): 449-472.

Brungger, Heinrich (1996): The U se of Purchasing Power Parities in International Comparisons, presented at the First Meeting of the Canberra G roup, Expert G roup on Household Income Statistics, Canberra (Australia), D ecember 1996.

Buhmann, Brigitte/ Rainwater, Lee/ Schmaus, Günther/ Smeeding, Timothy M. (1988): Equivalence scales, well-being, inequality and poverty: sensitivity estimates across ten countries using the Luxembourg Income Study (LIS) database, Review of Income and W ealth 34: 114-142.

Castles, Francis G./ Mitchell, D eborah (1993): Worlds of welfare and families of nations, in Castles, Francis (ed.) Families of N ations: Patterns of Public Policy in W estern D emocracies, Aldershot: D artmouth: 93-128.

Corden, Anne (1995): Changing Perspectives on Benefit Takeup, London: HMSO.

D eacon, Bob/ Bradshaw, Jonathan R. (1983): Reserved for the Poor: The Means-T est in British Social Policy, London: Martin Robertson.

Eardley, Tony/ Bradshaw, Jonathan/ Ditch, John/ Gough, Ian/ Whiteford, Peter (1996a): Social Assistance in OECD Countries, Volume I: Synthesis Report, Department of Social Security Research Report, London: HMSO.

Eardley, Tony/ Bradshaw, Jonathan/ Ditch, John/ Gough, Ian/ Whiteford, Peter (1996b): Social A ssistanœ in OE CD C ountries, V olume II: Country Reports, D epartment of Social Security Research Report No. 46, London: HMSO. 
Esping-Andersen, Gøsta (1990): The T hree W orlds of W elfare Capitalism, Cambridge: Polity.

Esping-Andersen, Gøsta (1999): Social F oundations of Postindustrial E conomies, Oxford: Oxford University Press.

European Commission (1999): A C oncerted Strategy for Modernising Social Protection, Brussels: European Commission.

Förster, Michael F. (1994): The effects of net transfers on low incomes among non-elderly families, OE CD E conomic Studies (22): 181-221.

George, Vic/ Lawson, Roger (1980): Introduction, in G eorge, Vic/ Lawson, Roger (eds.): Poverty and Inequality in Common M ark et C ountries, London: Routledge \& Kegan Paul.

Goodin, Robert E./ Headey, Bruce/ Muffels, Ruud A./ Dirven, Henk-Jan (1999): The Real W orlds of $W$ elfare Capitalism, Cambridge: Cambridge University Press.

Gordon, D avid/ Spicker, Paul (eds.) (1999): The International G lossary on Poverty, London: Zed Books.

Guibentif, Pierre/ Bouget, Denis (1997): Mindesteink ommen in der E uropäischen Union: E in sozialpolitischer V ergleich, Lissabon: União des Mutualidades Portuguesas.

Gustafsson, Björn A./ Uusitalo, Hannu (1990): The welfare state and poverty in Finland and Sweden from the mid-1960s to the mid-1980s, Review of Inome and W ealth 36 (3): 249-266.

Halleröd, Björn (1991): D en svenska fattigdomen: E n studie av fattigdom och socialbidragstagande, Lund: Arkiv förlag.

Hauser, Richard (1987): Comparing the Influence of Social Security Systems on the Relative Economic Positions of Selected Groups in Six Major Industrialized Countries: The Case of One-Parent Families, E uropean E conomic Review 31 (1-2): 192201.

Hauser, Richard/ Fischer, Ingo (1990): Economic well-being among one-parent-families, in Smeeding, Timothy M./ O 'Higgins, Michael/ Rainwater, Lee (eds.): Poverty, inequality and income distribution in comparative perspective, Hemel Hempstead: Harvester Wheatsheaf: 126-157.

Jäntti, Markus/ D anziger, Sheldon H. (2000): Income Poverty in Advanced Countries, in Atkinson, Anthony B./ Bourguignon, François (eds.): H andbook on Income D istribution, Amsterdam: Elsevier: 309-378.

Kangas, Olli E./ Ritakallio, Veli-Matti (1998a): Different methods - different results? Approaches to multidimensional poverty, in Andreß, Hans-Jürgen (ed.) E mpirical Poverty Research in a Comparative Perspective, Aldershot: Ashgate: 167-204.

Kangas, Olli E./ Ritakallio, Veli-Matti (1998b): Social Policy or Structure? Income Transfers, Sociodemographic Factors and Poverty in the $\mathrm{N}$ ordic C ountries and in F ranœ, Luxembourg Income Study Working Paper Series No. 190, Luxemburg: LIS.

Krämer, Walter (1997): Statistische Probleme bei der A rmutsmessung, Gutachten im A uftrag des Bundesministeriums für $\mathrm{G}$ esundheit, Baden-Baden: Nomos. 
Krämer, Walter (2000): A rmut in der Bundesrepublik: Z ur Theorie und Prax is eines überforderten Begriffs, Frankfurt (Main)/ New York: Campus.

Leibfried, Stephan (1992): Towards an European Welfare State? On Integrating Poverty Regimes into the European Community, in Ferge, Zsuzsa/ Kolberg, Jon Eivind (eds.): Social Policy in a Changing Europe, New York/ Frankfurt (Main): Campus/ Westview: 245-279.

Lødemel, Ivar/ Schulte, Bernd (1992): Social Assistance: a part of social security or the poor law in new disguise?, in Security, European Institute of Social (ed.) Reforms in E astern and C entral E urope: Beveridge 50 years after, Leuven: Acco: 515-538.

McFate, Katherine/ Smeeding, Timothy/ Rainwater, Lee (1995): Markets and states: poverty trends and transfer system effectiveness in the 1980s, in McFate, Katherine/ Lawson, Roger/ Wilson, William Julius (eds.): Poverty, inequality, and the future of social policy, New York: Russell Sage Foundation: 29-66.

Mitchell, D eborah (1991): Income T ransfers in T en W elfare States, Aldershot: Avebury.

OECD (1998a): The Battle A gainst E x dusion: Social A ssistance in A ustralia, Finland, Sweden and the U nited Kingdom, Paris: OECD.

OECD (1998b): The Battle A gainst E x dusion: Social A ssistance in Belgium, the C zech Republic, the $\mathrm{N}$ etherlands and N orway, Paris: OECD.

OECD (1999): The Battle A gainst E x dusion: Social A ssistance in Canada and Switzerland, Paris: OECD.

Pedersen, Axel West (1999): The Taming of Inequality in Retirement: A Comparative Study of Pension Policy 0 utcomes, Fafo Report No. 317, O slo: FAFO.

Ringen, Stein (1987): The Possibility of Politics: A Study in the Political E conomy of the W elfare State, Oxford: Clarendon.

Shaver, Sheila (1998): Universality and Selectivity in Income Support: An Assessment of the Issues, Journal of Social Policy 27 (2): 231-254.

Smeeding, Timothy M./ O 'Higgins, Michael/ Rainwater, Lee (eds.) (1990): Poverty, Inequality and Income Distribution in Comparative Perspective, Hemel Hempstead: Harvester Wheatsheaf.

Smeeding, Timothy M./ Ross, Katherin (1999): Social Protection for the Poor in the D eveloped W orld: The E videnœ from L IS, Luxembourg Income Study Working Paper Series No. 204, Luxemburg: LIS.

Titmuss, Richard (1974): Social Policy, London: Allen \& Unwin.

van Oorschot, Wim (1991): Non-take-up of social security benefits in Europe, Journal of E uropean Social Policy 1 (1): 15-30.

van O orschot, Wim (1995): Realizing Rights: A Multi-level A pproach to N on-takeup of Social Security Benefits, Aldershot: Avebury.

van Oorschot, Wim (1998): Failing selectivity: On extent and causes of non-take-up of social security benefits, in Andreß, Hans-Jürgen (ed.) E mpirical Poverty Research in a Comparative Perspective, Aldershot: Ashgate: 101-132. 
Veit-Wilson, John (1998): Setting A dequacy Standards: H ow Governments D efine Minimum Incomes, Bristol: Policy Press. 


\section{$7 \quad$ Appendix}

\subsection{Data used in this study}

Table 7.1: $\quad$ Construction of $L$ IS datasets

\begin{tabular}{|c|c|c|c|}
\hline Country & Y ear & Source & Sample Size \\
\hline Australia & 1994 & Australian Income and Housing Survey & \\
\hline Canada & 1994 & Survey of Consumer Finances & \\
\hline D enmark & 1992 & Income Tax Survey & \\
\hline Finland & 1995 & Income Distribution Survey & \\
\hline France & 1994 & Family Budget Survey & \\
\hline Germany & 1994 & G erman Sozio-economic Panel (G SOEP) & \\
\hline Italy & 1995 & $\begin{array}{l}\text { The Bank of Italy Survey (Indagine Campionaria sui Bilanci } \\
\text { D elle Famiglie) }\end{array}$ & \\
\hline Luxembourg & 1994 & $\begin{array}{l}\text { The Luxembourg Social Economic Panel Study „Liewen zu } \\
\text { Letzebuerg“ }\end{array}$ & \\
\hline Netherlands & 1994 & Socio-Economic Panel (SEP) & \\
\hline Norway & 1995 & $\begin{array}{l}\text { Income and Property D istribution Survey (Inntekts- og } \\
\text { Formuesundersokelsen) }\end{array}$ & \\
\hline Sweden & 1995 & $\begin{array}{l}\text { Income Distribution Survey } \\
\text { (Inkomstfördelningsundersokningen) }\end{array}$ & \\
\hline United Kingdom & 1995 & The Family Expenditure Survey & \\
\hline United States & 1994 & March Current Population Survey & \\
\hline
\end{tabular}

Souro: L IS documentation.

\subsection{Methodology of the estimation of social assistance benefit levels}

The following methodology has been applied to estimate the level of social assistance levels (cf. Behrendt 2000c). The following minimum income benefits are available for the model households chosen. Basically, all households are assumed to be eligible to the full amount of social assistance. Since benefit rates may considerably vary across municipalities in Sweden, the recommended rates are used here as a guideline, yet the benefits actually paid out may deviate from these values. The marginal regional variation of standard benefit rates in Germany are taken into account by using the average standard benefit rate of the „old L änder”. 30 The „new L änder” will not be considered here. 31

30 Since social assistance standard benefit rates are usually updated in the middle of the year, the yearly average has been chosen as the reference amount.

31 In Eastem Germany, benefit levels are slightly lower than in the West, but wages and prices (notably rents) have not reached yet the Western level either. 
Since the purpose of this analysis is the assessment of the adequacy of the minimum income level set by social assistance, all households are assumed to have no earnings or capital income, so no income disregards and special premiums for working claimants are to be considered. Likewise, it is assumed that these families do not have any entitlements to social insurance benefits that require previous contributions or the fulfilment of other conditions. Thus, unemployment benefit or minimum pensions are not taken into account. The calculation of social assistance entitlements should however consider universal social security benefits that are not dependent on previous contributions and are fully disregarded in the calculation of social assistance. This type of benefits therefore increases the amount of disposable income for a broad majority of the claimant population. The above mentioned German parent allowance fits into this category. This benefit is fully disregarded in the calculation of social assistance benefits and thus adds to the total social assistance claim. O ne could argue that the Swedish basic pension would also meet these criteria, but benefits are conditional upon previous long-standing residency in Sweden. Since many recipients of social assistance in Sweden are refugees, they cannot meet these criteria and thus have to fully rely on social assistance anyway. For the calculation of social assistance entitlements, the basic pension is therefore not considered.

In addition, the model families may be entitled to special premiums that are supposed to meet additional needs of specific claimant categories. The model calculations include family premiums (Britain), single parent premiums (Britain and $\mathrm{G}$ ermany), as well as additions in case of old age (Britain and G ermany). Other premiums, such as premiums in case of disability or pregnancy, were not taken into account since this would unduly constrain the generalisation of results. Since the Swedish recommended benefit rates lack any stipulated premiums for special needs, there are no premiums taken into account for Sweden.

Standard benefit rates have to be further complemented by the value of one-off benefits. One-off benefits can make up a considerable share of the total amount of social assistance benefits people receive, but it is difficult to gauge the exact amount of one-off benefits people receive since these benefits are - by definition - based on individual needs that cannot easily be standardised. The assessment of social assistance entitlements can therefore only be based on broad estimates of the value of one-off benefits. In the $G$ erman case, the social assistance benefit level has been augmented by $16 \%$ based on the evidence on average expenditure on one-off benefits. For the United Kingdom, the amount of one-off benefits from the social fund has assumed to be equal to the average net expenditure of the social fund per recipient of income support. For Sweden, there is no systematic evidence available on the amount of one-off benefits actually paid, therefore this income component could not be considered in this calculation. However, since some of the items covered by one-off benefits in Germany and Britain are covered by the standard benefit rate in Sweden, the level of the social assistance package should be comparable. 
The final major component of recipients' households total income is made up by benefits to cover the cost of housing. ${ }^{32}$ Since rent levels vary strongly within countries and also across countries, our calculation has to rely on a broad estimation of housing cost. For Germany, the housing costs are gauged on the basis of the official statistics on the average housing costs of recipients of social assistance differentiated according to household size. The housing cost for social assistance households in Britain and Sweden have been approximated on the basis of rent levels for York and Stockholm (cf. Eardley et al. 1996a: 114).

The addition of these four income components makes up the total benefit entitlement of recipients of social assistance. The value of social assistance entitlements is shown by Chart A-1, referring to the value of the monthly benefit package after housing cost in ECU adjusted for differences in purchasing power. 33

32 The model calculations are based on the assumption that recipient households have their full rent paid by social assistance or related schemes, provided that the rent level is considered as reasonable by the social assistance authorities. The results strongly depend on the underlying assumptions concerning the level of housing costs, however. Since housing costs are subject to large cross-country and regional variation, and strongly depend on the size and quality of the accommodation, actual social assistance levels after housing may markedly diverge from the levels reported in these model calculations.

33 Purchasing-power based comparisons of income level across countries are very sensitive towards variations in the measure of purchasing power. There may be large differences in the measured income level if the calculations are based on purchasing power parities from a different source or use a slightly modified definition (cf. Brungger 1996). In addition, national purchasing power parities may not be able to catch the specific consuming patterns of low income groups since they rely on an overall measurement of prices. These absolute measures should therefore be complemented by additional indicators of income levels based on relative measurement. 
Chart A -1: L evel of social assistance entitlements for different family types, after housing cost (1995)

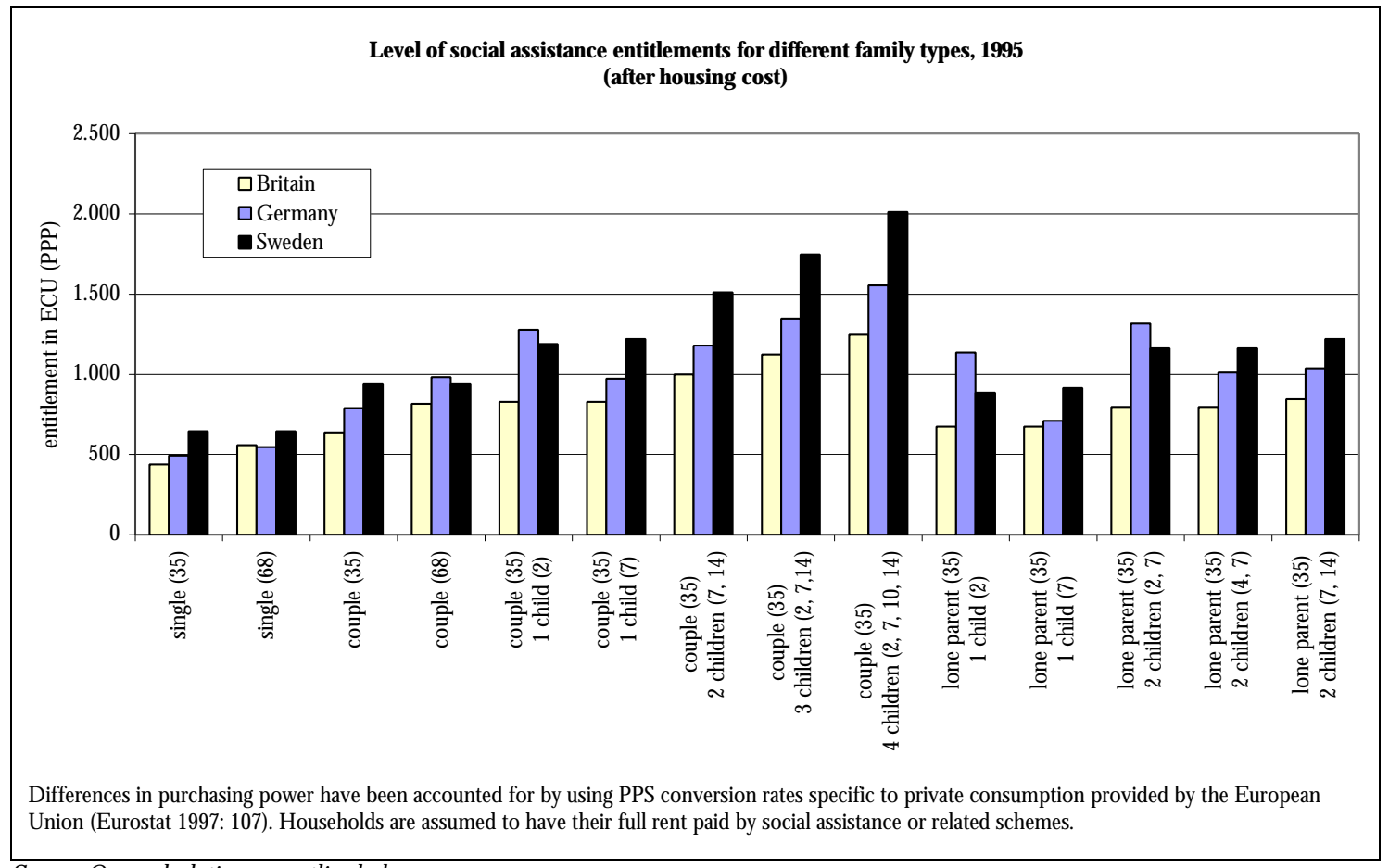

Souro: 0 wn calculations as outlined above. 